\title{
Raw rubber and viscoelastic properties of organoclay filled latex crepe rubber
}

\author{
H G I M Wijesinghe*, U N Ratnayake**, A Alakolanga* and N S Withanage* \\ * Faculty of Animal Science and Export Agriculture Uva Wellassa University, Sri Lanka \\ **Rubber Research Institute of Sri Lanka, Telawala Road, Ratmalana, Sri Lanka
}

\begin{abstract}
Organoclay $(O C)$ filled natural rubber $(N R)$ latex crepe was prepared in view of investigating the effect of organoclay on raw rubber properties and viscoelastic properties by incorporating aqueous dispersion of OC clay into NR latex followed by conventional acid coagulation procedure.

Raw rubber properties of $O C$ filled fractionated bleached $(F B)$ and unfractionated unbleached (UFUB) crepe rubber were evaluated to characterized the composite samples in comparison to standard crepe rubber whilst process based characterization was carried out with Moony viscosity and Mooney relaxation data. Raw rubber properties have shown that OC acts as a pro-oxidant and as a result, Initial Plasticity (Po) and Plasticity Retention Index (PRI) which measures the thermo-oxidative degradation were negatively affected. Viscoelastic behaviour, as measured with low shear strain rate flow properties, is significantly affected by the addition of $O C$ into the NR latex. Reduction of Mooney viscosity of OC filled crepe rubber has been explained with thermal oxidation as a result of metal impurities in the $O C$ and plasticization caused by the organic modifier of the OC. Mooney stress relaxation has shown that lower clay loading provides a better processability and dispersion of $O C$ within the crepe rubber.
\end{abstract}

Key words: crepe rubber, Natural rubber, organoclay (OC), Mooney viscosity, Mooney stress relaxation, raw rubber properties, thermo-oxidative degradation

\section{Introduction}

Natural Rubber (NR) obtained from Hevea brasiliensis is one of the most important engineering raw materials for different industrial applications. Among the different types of NR grades, NR latex crepe is considered as the purest form of NR. After removing non-rubber substituents from the field latex by fractionation and bleaching processes, fractioned bleached (FB) crepe rubber can be obtained whilst without 
following these two steps un-fractioned unbleached (UFUB) crepe rubber is produced (Senevirathne and Kumara, 2003). Latex crepe is mostly utilized to manufacture of pharmaceutical and surgical articles, infant toys and food contact articles.

NR is widely used to manufacture of engineering products due to its excellent mechanical properties (Onyeagoro G.N., 2013) and due to some of the other advantages such as superior dynamic properties, low heat build-up and excellent tack (De Silva K.G.K., 2003). Although NR has a superior green strength, less stiffness and poor dimensional stability obstruct NR applications in engineering products. Therefore, in the manufacture of rubber products, reinforcing fillers are used to improve the physico-mechanical properties and to reduce the cost of the products. Reinforcing fillers such as carbon black and silica are widely used but carbon black causes environmental pollution (Alwis et al., 2014). Silica is widely used to manufacture of lighter coloured rubber products (Chonkaew et al., 2011).

Recently, polymeric nanocomposites have attracted a greater interest in academia and industry due to its unique properties than conventional polymer composites (Ratnayake et al., 2008; Alwis G.M.C. et al., 2014). Further, NR nanocomposites have shown a significant improvement in physicomechanical properties at lower loading levels of nanomaterial as filler over conventional rubber composites containing carbon black and silica. Among the nanomaterial/nanofiller, montmorillonite (MMT) clay is one of the widely researched reinforcing filler for rubber applications due to its higher aspect ratio of 50-300 and higher specific surface area of $750-800 \mathrm{~m}^{2} / \mathrm{g}$.

The clay platelets/layers in MMT clay particles are separated by a gallery space, which consists of hydrated cations such as $\mathrm{Na}^{+}, \mathrm{K}^{+}$and water molecules. It has been identified that several active sites such as a few positive charges, hydroxyl groups and negative charges are present on the surface of MMT clay crystals (Utracki, 2004). MMT clay crystals are made out of a large number of individual clay platelets/layers with a $1 \mathrm{~nm}$ thickness and a few microns in other dimensions (Brindley and Brown, 1980; Ray and Okamotoa, 2003). The space between two successive layers of hydrophilic MMT is too small to diffuse polymer molecules into the gallery space (Utraki, 2004) and, as a result, it is a challenge to incorporate hydrophilic MMT into hydrophobic NR (Alwis et al., 2014). However, organic modification of MMT with the use of quaternary ammonium salts produces organonophilic montmorillonite clay (OMMT), in which compatibility with NR has been improved (Gatos and Kocsis, 2010).

Incorporation of MMT clay into rubber matrix can be achieved in different ways such as melt mixing, latex compounding and etc. (Gatos and Kocsis, 2010). However, incorporation of MMT clay at the NR latex stage and 
H G I M Wijesinghe et al.

followed by coagulation is an easy and economical compared to that of other methods as reported by Li-Qun Zhang, 2010. However, to achieve a better reinforcement and processability, MMT clay should be exfoliated/delaminated with in the rubber matrix into individual platelets, a $1 \mathrm{~nm}$ thickness (Alwis et al., 2014).

Preparation of MMT clay filled NR latex crepe rubber and its effect on properties have not been reported in the literature. Therefore, developing a novel NR latex crepe rubber with different characteristics would be advancement in the crepe rubber industry.

The objective of the study reported here is to prepare organoclay (OC) filled latex crepe rubber with an optimum dispersion of organoclay and to investigate the effect of nanostructures of $\mathrm{OC}$ on raw rubber properties and viscoelastic properties of the crepe rubber.

\section{Materials and Methods \\ Materials}

Natural rubber (NR) latex with $30 \%$ dry rubber content (DRC) obtained from Dartonfield rubber factory, Rubber Research Institute was used to manufacture organoclay (OC) filled NR latex crepe rubber. Montmorillonite (MMT) clay (Cloisite 20A) modified with dimethyl dihydrogenated tallow ammonium salt and with an ignite weight loss of $43-45 \%$ supplied by Southern Clay Products, Inc. Co. Ltd. was used to prepare organoclay (OC) filled latex crepe rubber. Other general compounding chemicals used were of commercial grade.

\section{Characterization of Organoclay}

Metal ions such as iron and copper were analyzed to find out the metal impurities available within the OC. Concentrated hydrochloric acid was added to ashed organoclay samples and they were kept on a water bath for 20 minutes for the digestion at $60{ }^{\circ} \mathrm{C}$. Digested samples were analyzed for metal ions with an Atomic Absorption Spectrophotometer (AAS), model Avanta series CAN 005471686.

Preparation of organoclay (OC) filled NR latex crepe rubber

Organoclay filled fractionated bleached crepe rubber (OFBC) and unfractionated unbleached crepe rubber (OUFUBC) were prepared by incorporating organoclay dispersion into NR latex followed by standard manufacturing procedure of NR latex crepe rubber (Senevirathne and Kumara, 2003). Table 1 illustrates the organoclay loading for each type of crepe rubber.

An aqueous dispersion of 5\% (w/w) organoclay was prepared by mixing organoclay (OC) in water in the presence of small amount of anionic surfactant and 10\% (w/w) potassium laurate soap. 
Table 1. Organoclay $(O C)$ filled NR latex crepe rubber samples

\begin{tabular}{ccc}
\hline $\begin{array}{c}\text { Organoclay } \\
\text { amount (phr) }\end{array}$ & $\begin{array}{c}\text { Fractioned } \\
\text { bleached (FB) }\end{array}$ & $\begin{array}{c}\text { Unfractionated unbleached } \\
\text { (UFUB) }\end{array}$ \\
\hline $\mathbf{0}$ & OFBC -0 & OUFUBC -0 \\
$\mathbf{2}$ & OFBC -2 & OUFUBC -2 \\
$\mathbf{4}$ & OFBC -4 & OUFUBC -4 \\
$\mathbf{6}$ & OFBC -6 & OUFUBC -6 \\
$\mathbf{8}$ & OFBC -8 & OUFUBC -8 \\
\hline
\end{tabular}

The last digit shows the amount of organoclay loading and ' 0 ' denotes the reference sample where it contains no clay.

\section{Characterization of raw rubber properties}

Ash content in the OFBC and OUFUBC was measured to evaluate the Aluminosilicate (i.e. inorganic material) content in the rubber according to the standard test method of SO 247: 1990 (E) (Test method A) using Gallenkamp muffle furnace (Size 2/Tactical 308).

Clay recovery percentage in both crepe rubber types was computed to assess the amount of organoclay (OC) retained in both crepe rubber samples. It was calculated based on the ash content present in the OC filled crepe rubber samples as per the below equation.

$$
\text { Clay recovery } \%=\frac{(\mathrm{M} 1-\mathrm{M} 2)+\mathrm{M} 3}{\mathrm{M}} \times 100 \%
$$

Where, $\mathrm{M}$ is the actual added amount of organoclay into $1 \mathrm{~kg}$ of rubber, M1 is total ash content of organoclay filled crepe rubber (layered aluminosilicate plus inorganic metal oxides), M2 is ash content of unfilled crepe rubber (metal oxides in the control samples) and M3 is theoretical organic modifier content (43-45\%) which has been burnt off during the ashing process.

The effect of dispersed clay structures on stiffness of both OFBC and OUFUBC composite samples was measured with Initial Plasticity $\left(\mathrm{P}_{\mathrm{o}}\right)$ of the raw rubber. $\mathrm{P}_{\mathrm{o}}$ of the $\mathrm{OC}$ filled crepe rubber samples was performed by Wallace Rapid Plastimeter, MkV model at $100^{\circ} \mathrm{C} \pm 1{ }^{\circ} \mathrm{C}$ as standard test method of ISO 7323:2006 (E).

Plasticity Retention Index (PRI), which measures the resistance to thermooxidative degradation of NR unvulcanized raw rubber was used to evaluate the effect of organoclay on thermo-oxidative stability of OC filled latex crepe rubber composites. PRI was 
H G I M Wijesinghe et al.

measured by analyzing the $\mathrm{P}_{\mathrm{o}}$ before and after ageing at $140^{\circ} \mathrm{C}$ for half an hour using the same plastimeter as per the ISO 2930:2009 (E). PRI of the organoclay filled crepe rubber was calculated as per the below standard equation.

PRI $=\frac{\mathbf{P}_{30}}{\mathbf{P}_{0}} \times 100 \%$

where, $\mathrm{P}_{30}-$ aged rapid plasticity number after aging the sample for 30 minutes $140{ }^{\circ} \mathrm{C}$ and $\mathrm{P}_{0}$ - unaged initial rapid plasticity of rubber at room temperature.

Measuring of nitrogen content in organoclay (OC) filled latex crepe rubber composite samples is important to identify the effect of ammonium modifier in organoclay (OC) on the raw rubber properties and viscoelastic properties. Kjeldahl method as in ISO 1656:2014 (E) was carried out in order to estimate the nitrogen content in organoclay (OC) filled latex crepe rubber composites.

Volatile matter content represents mostly the amount of moisture in crepe rubber and low molecular weight volatile compounds. Higher amount of moisture have the potential to behave as a plasticizer for NR. ISO 248 Part I: 2011 (E) standard test method was used to determine the volatile matter content.

\section{Characterization of viscoelastic behaviour}

Mooney viscosity, a measure of resistance to flow at low shear strain rate, of OC clay filled NR latex crepe rubber was investigated to study the effect of OC clay structures on processability of the NR composites. Initial peak of Mooney curve indicates the viscosity at the on-set of the test; it is a function of the green strength of rubber (ASTM D 1646 - 04). The investigation of Mooney viscosity and initial peak of the organoclay filled crepe rubber composites was performed according to the ISO/R 289-1: 2014 (E) using Ektron Mooney viscometer, model EKT $2001 \mathrm{M}$.

\section{Mooney stress relaxation (MSR)}

Mooney stress relaxation, which correlates to the elastic behaviour of rubber, was analyzed to study how dispersed organoclay structures affect the elastic behaviour of the NR composites. Mooney stress relaxation curve was obtained by stopping the rotor immediately after the Mooney viscosity test and recording Mooney values in 20 seconds intervals for 2 minutes. Stress relaxation of rubber can usually be explained with by power law model,

$\mathbf{M}=\mathbf{k}(\mathbf{t})^{\mathrm{a}}$

where $\mathrm{M}$ is torque value in Mooney units and $\mathrm{a}$ is the rate of stress relaxation (Malac 2011)

$\log M=\mathbf{a} \log t+\log k$ 
The slope, (a) of log-log plot of power law model is one method of quantifying uncured rubber elasticity and a steep slope indicates less uncured elasticity result in better processability (Malac J., 2009). Also the stress relaxation is the response to a sudden cessation of deformation, when the rotor of the Mooney viscometer stops. The rate of stress relaxation can correlate with molecular structure characteristics such as molecular weight distribution, chain branching and gel content (Rogers M. B. et al, 2005).

\section{Results and Discussion Characterization of organoclay}

The analysis of ash content shows that inorganic content in the organoclay is $52 \%-58 \%$ indicating the balance of 48 $-42 \%$ is organic modifier percentage and it is in agreement with the supplier information. This ash content represents the amount of aluminosilicates and other inorganic metal oxide present in the organoclay. Total copper and iron concentration in the organoclay as impurities shown in Table 2 are 1.54 ppm and $540 \mathrm{ppm}$ respectively. Higher amount of these metal ions, known as pro-oxidants, are likely to affect the raw rubber properties and processability of the organoclay filled crepe rubber.
Table 2. Metal ion content in organoclay

\begin{tabular}{lc}
\hline Metal ion & ppm \\
\hline Total copper & 1.94 \\
Total iron & 540.56 \\
\hline
\end{tabular}

Raw rubber properties of organoclay filled crepe rubber

Both organoclay filled fractionated bleached crepe rubber (OFBC) and organoclay filled un-fractionated unbleached crepe rubber (OUFUBC) samples were compared with the average raw rubber properties of the NR latex crepe rubber (Hand Book of Rubber Processing Technology, RRISL). Table 3 presents raw rubber properties of OFBC-0 and OUFUBC-0 samples containing no OC. According to the results obtained for each raw rubber property, average raw rubber properties of the both samples are comply with standard specifications shown by Senevirathne et al., 2003 in Hand Book of Rubber Processing Technology, RRISL. According to De Silva, K.G.K., 2003, it has been reported that the volatile matter content of UFUB crepe rubber can be higher than that of FB crepe rubber because of the higher percentage of proteins along with other non-rubbers absorb moisture. 
H G I M Wijesinghe et al.

Table 3. Average raw rubber specifications of crepe rubber composites

\begin{tabular}{llrr}
\hline Property & Specification & OFBC -0 & OUFUBC -0 \\
\hline Volatile matter\% (w/w) & $0.5 \%(\max )$ & 0.23 & 0.30 \\
Ash content\% (w /w) & $0.20(\max )$ & 0.16 & 0.07 \\
P $_{\mathbf{0}}$ (Wallace units) & $30(\mathrm{~min})$ & 38.6 & 44.15 \\
PRI (Wallace units) & $60(\mathrm{~min})$ & 62.52 & 78.2 \\
Nitrogen content\% (w/w) & $0.35(\max )$ & 0.31 & 0.34 \\
Mooney viscosity & $75-85$ & 75.85 & 76.9 \\
\hline
\end{tabular}

Mooney viscosity of OFBC-0 and OUFUBC-0 are not significantly deviated from the recommended range but it is high in OUFUBC-0 sample because non-rubbers can influence to resist the thermo-oxidative degradation of NR at the testing temperature of 100 ${ }^{\circ} \mathrm{C}$ at low shear strain rate. In addition, non-rubbers especially proteins improves the stiffness of NR by acting as filler which can affect to increase the $\mathrm{P}_{\mathrm{o}}$ and Mooney viscosity.

\section{Organoclay recovery percentage}

Clay recovery percentage was calculated based on the ash contents in both organoclay filled latex crepe rubber composite samples (OFBC and OUFUBC) to determine the effective clay percentage retained within the crepe rubber. As shown in Table 4, clay recovery percentage decreases with the increase of organoclay loading in both types of the crepe rubber composite samples. As expected, small percentage of organoclay has been washed off with the serum during processing. However, slightly higher organoclay recovery percentage was resulted in FB crepe rubber than UFUB crepe rubber.

Non-rubber substances which are lower molecular weight macromolecules such as proteins may have a potential to intercalate into the interlayer spacing of the organoclay better than rubber molecules due to their smaller sizes. This could be the reason for removing more clay with the serum during processing of OUFUBC than OFBC composites.

Table 4. Clay recovery percentage in organoclay filled latex crepe rubber

\begin{tabular}{lclc}
\hline Sample code & Clay recovery $(\%)$ & Sample code & Clay recovery (\%) \\
\hline OFBC-0 & - & OUFUBC-0 & - \\
OFBC-2 & 97.30 & OUFUBC-2 & 96.53 \\
OFBC-4 & 97.82 & OUFUBC-4 & 89.11 \\
OFBC-6 & 94.66 & OUFUBC-6 & 89.46 \\
OFBC-8 & 93.78 & OUFUBC-8 & 87.94 \\
\hline
\end{tabular}




\section{Raw rubber properties of organoclay filled crepe rubber}

Raw rubber properties of both organoclay filled latex crepe rubber (OFBC and OUFUBC) with increasing organoclay loading are shown in Table 5 and 6 where compared with that of average raw rubber properties of the crepe rubber. As expected, volatile matter content (VM \%) in both OFBC and OUFUBC composites increases with the filler loading.

Volatile matter content of OUFUBC composites is higher than that of OFBC composites because of the presence of proteins along with other non-rubbers substances results in absorption of water (De Silva, K.G.K., 2003). However, volatile matter content has not exceeded the critical value of $0.5 \%$. Therefore, volatile matter, mostly the absorbed, moisture could not have a significant effect on physical properties of the clay filled crepe rubber.

Nitrogen content in both OFBC and OUFUBC composites has shown an increasing trend with the increase of organoclay loading as organic modifier, dimethyl dihydrogenated tallow ammonium contains nitrogen. Ratnayake et al., (2009), has reported that maximum critical limits for copper and iron ions in NR latex crepe rubber are $1.6 \mathrm{ppm}$ and $30 \mathrm{ppm}$ respectively. As shown in Table 5 and 6, both OFBC and OUFUBC composite samples, especially samples prepared with higher dosages of organoclay, contained higher concentration of iron and copper due to the higher amount of copper and iron ion contaminations in the organoclay.

Table 5. Raw rubber properties of OFBC composites

\begin{tabular}{lccccc}
\hline Sample code & VM\% & Ash\% & N\% & $\begin{array}{c}\text { Total iron ions } \\
(\mathbf{p p m})\end{array}$ & $\begin{array}{c}\text { Total copper } \\
\text { ion (ppm) }\end{array}$ \\
\hline OFBC-0 & 0.23 & 0.16 & 0.31 & 17.98 & 1.48 \\
OFBC-2 & 0.27 & 1.22 & 0.34 & 30.47 & 1.49 \\
OFBC-4 & 0.33 & 2.28 & 0.36 & 42.96 & 1.51 \\
OFBC-6 & 0.36 & 3.28 & 0.39 & 55.45 & 1.53 \\
OFBC-8 & 0.42 & 4.28 & 0.44 & 67.94 & 1.55 \\
\hline
\end{tabular}

Table 6. Raw rubber properties of OUFUBC composites

\begin{tabular}{lccccc}
\hline Sample code & VM\% & Ash\% & N\% & $\begin{array}{c}\text { Total iron ions } \\
(\mathbf{p p m})\end{array}$ & $\begin{array}{c}\text { Total copper ion } \\
(\mathbf{p p m})\end{array}$ \\
\hline OUFUBC-0 & 0.30 & 0.07 & 0.34 & 20.12 & 1.43 \\
OUFUBC-2 & 0.31 & 1.04 & 0.38 & 42.61 & 1.44 \\
OUFUBC-4 & 0.34 & 1.92 & 0.41 & 55.10 & 1.46 \\
OUFUBC-6 & 0.39 & 2.77 & 0.43 & 67.59 & 1.49 \\
OUFUBC-8 & 0.43 & 3.61 & 0.47 & 80.08 & 1.51 \\
\hline
\end{tabular}


H G I M Wijesinghe et al.

As shown in Figure 1, Initial plasticity $\left(\mathrm{P}_{\mathrm{o}}\right)$ of FBC-2 and OUFUBC-2 has reduced by $21.7 \%$ and $31.78 \%$ respectively at $2 \mathrm{phr}$ organoclay loading. As expected, $\mathrm{P}_{\mathrm{o}}$ of OUFUBC is higher than that of OFBC composites in each clay loading and, in both cases, when organoclay loading increases more than $4 \mathrm{phr}, \mathrm{P}_{\mathrm{o}}$ has not significantly changed. According to these results the initial stiffness of $\mathrm{NR}$ has reduced significantly. This could be due to either thermal degradation of NR by the higher amount of iron and copper ions present in the organoclay or plasticization effect created as a result of organic modifier in the organoclay at $100{ }^{\circ} \mathrm{C}$ testing temperature.

In the preparation of OFBC samples the bleaching agent was added. It is also known that disulphide in bleaching agent has a tendency to reduce the molecular weight of NR by acting as a peptizing agent (Jana et al., 2006; Jana and Das 2005; Pipat et al., 2010). This disulphide in the FB crepe rubber could be a possible cause to reduce the stiffness of the rubber, resulting in reduced $\mathrm{P}_{\mathrm{o}}$ values (Ratnayake U.N., 2011). Poor interaction of NR molecules with OC stacks can also have a potential to plasticize the OFBC and OUFUBC composite samples. Plasticity of NR directly correlates with the molecular weight and the molecular weight distribution of NR. Therefore, it can be predicted that iron and copper ions have acted as a pro-oxidant for organoclay filled latex crepe rubber composites.

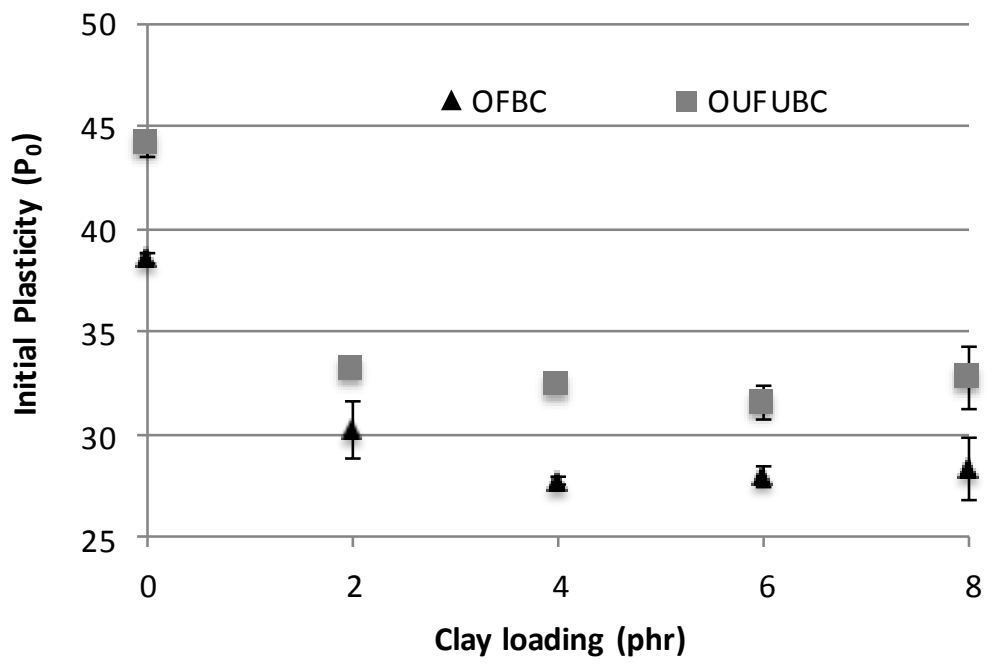

Fig 1. Initial plasticity of organoclay filled latex crepe rubber composites 
Plasticity Retention Index (PRI), which measures the resistance to thermooxidative degradation, of the crepe rubber samples was analyzed to evaluate the effect of OC clay on thermo-oxidative degradation. As shown in Figure 2, both OFBC and OUFUBC composites have indicated a significant reduction of PRI values compared to that of control samples of both when organoclay loading was increased.

OFBC-2 and OUFUBC-2 composites have shown $76.4 \%$ and $71.45 \%$ reduction of PRI respectively, indicating that clay accelerates the thermooxidative degradation. However, PRI values were not significantly changed beyond the $2 \mathrm{phr}$ loading of OC. PRI of OUFUBC composites is higher than that of the OFBC composites because OUFUBC composites contain natural antioxidants. As reported in Table 5 and 6 , total iron concentration in both composites is significantly higher compared to the critical value for crepe rubber (Ratnayake et al., 2009) and, as a result, marked reduction of PRI. Nicolaas Maria Huntink, (2003) has reported that metal ion catalyze decomposition of rubber when higher concentrations of copper and iron ions are present. The higher amount of iron and copper ions in the organoclay filled latex crepe rubber composites have a greater potential to accelerate the thermal degradation of NR and reduce the molecular weight by acting as a prooxidant.

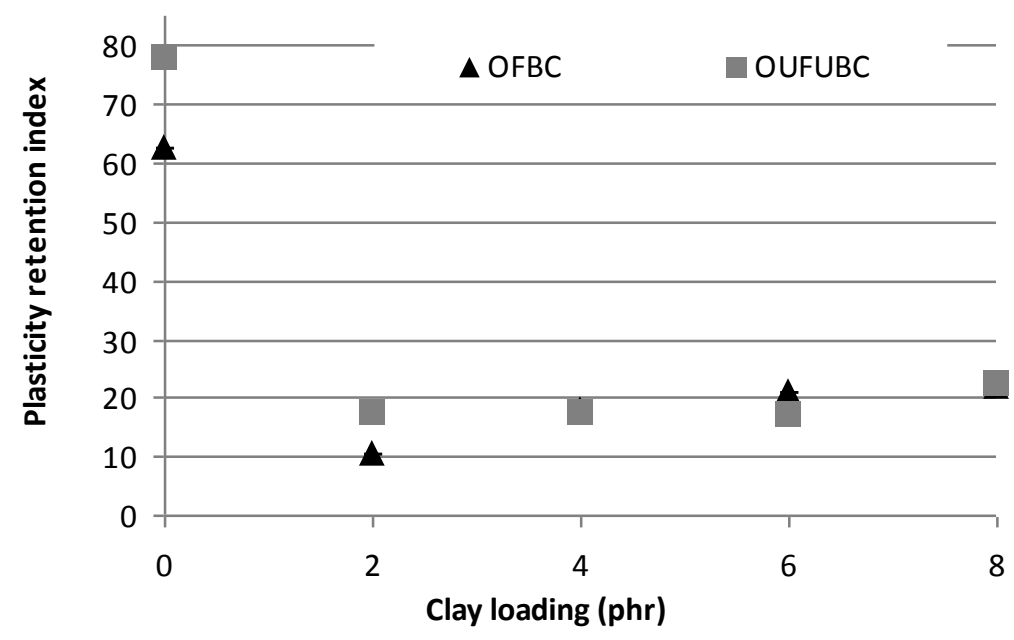

Fig 2. PRI of organoclay filled latex crepe rubber composites 
H G I M Wijesinghe et al.

$\mathrm{Fe}^{3+}$ ions in the NR latex has the ability to oxidize part of thiol which is used as bleaching agent in manufacturing of fractioned bleached crepe rubber. $\mathrm{Fe}^{3+}$ reduces the bleaching power of mercaptan thiol, simultaneously, it makes disulphides and it leads to oxidation or chain break of NR molecules (Michael and Swindell, 2000). $\mathrm{Fe}^{3+}$ ions are more effective in this action compared to $\mathrm{Fe}^{2+}$ as reported by Ratnayake et al., 2011. Higher amount of copper ions in the crepe rubber also has the same effect to degrade the NR by thermo-oxidation.

\section{Viscoelastic properties of organoclay filled latex crepe rubber}

Mooney curves obtained for organoclay filled latex crepe rubber composites are shown in Figure 3 and 4. Initial peak value which can be correlated to green strength of NR, Mooney viscosity and uncured elasticity of both types of crepe rubber containing $\mathrm{OC}$ were analyzed to study effect of OC on viscoelastic behaviour.

Figure 5 presents the Mooney viscosity of gum NR and organoclay filled crepe rubber samples. Incorporation of $2 \mathrm{phr}$ of organoclay has reduced Mooney viscosity of OFBC and OUFUBC by $12.9 \%$ and $13.8 \%$ respectively. Thereafter, Mooney viscosity has significantly reduced with the increase of organoclay loading levels and, as a result, marked deviation from the standard value of crepe rubber as reported by Seneviratne et al., 2003 in Handbook of Rubber Processing Technology, RRISL, indicating a significant effect on processability.

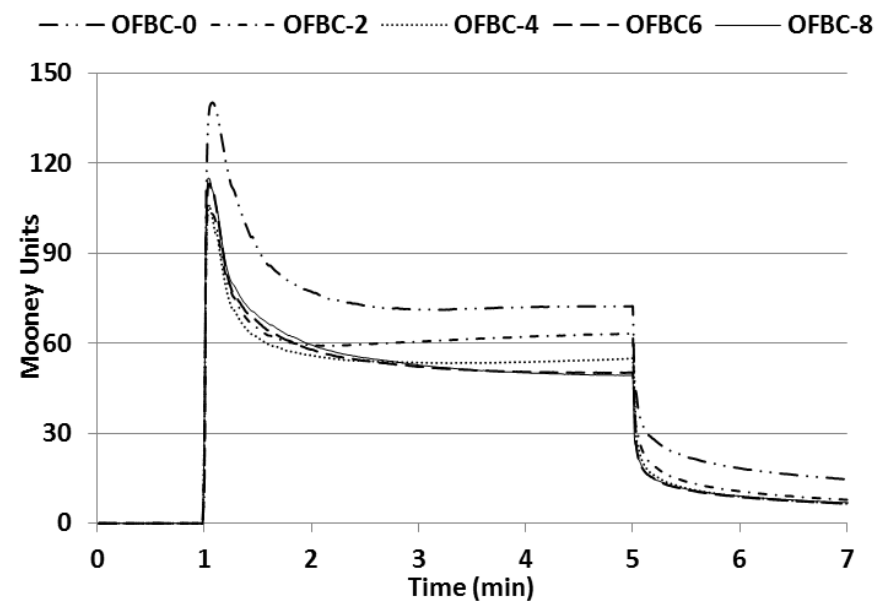

Fig 3. Mooney viscosity curves of OFBCR composites 


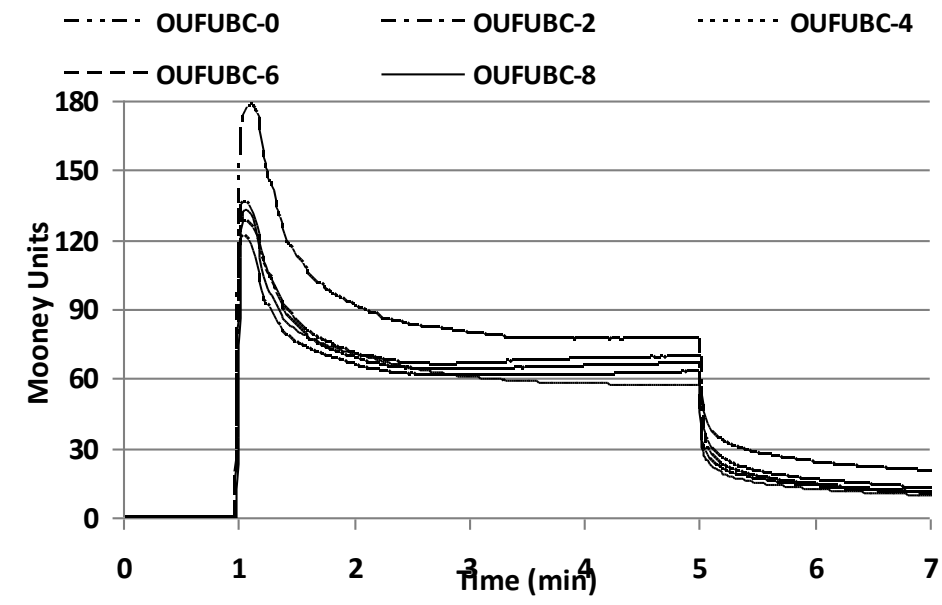

Fig. 4. Mooney viscosity curves of OUFUBC composites

The reason for the reduction of Mooney viscosity when increasing the organoclay loading could be the plasticization of NR molecules by organic modifier in the organoclay because smaller organic non-volatile molecules can act as plasticizers. Ratnayake \& Ketipearchchi (2012), have shown that organic modifiers used to modify MMT have a significant effect on thermo-oxidative degradation. Thermal oxidation can also be accelerated at the testing temperature of $100{ }^{\circ} \mathrm{C}$ as a result of containing higher concentration of metal ions, especially iron and copper ions.

Organoclay filled crepe rubber consists of higher amount of iron and copper ions that are higher than the critical limits and therefore accelerates the thermo-oxidative degradation as reported before. This would suggest that higher concentration of iron and copper ions in the organoclay filled crepe rubber has reduced the molecular weight of NR by thermal degradation and, therefore, reduce the Mooney viscosity.

There are some other reasons such as organoclay can absorb moisture because it is a highly hydroscopic material which swells in the presence of water and the moisture can plasticize the rubber and reduce the Mooney viscosity (Faheem, 2008). On the other hand, there may be a possibility of chain slippage over the clay platelets due to shear action by the rotor of Mooney viscometer (Cassagnau \& Barres, 2010). 


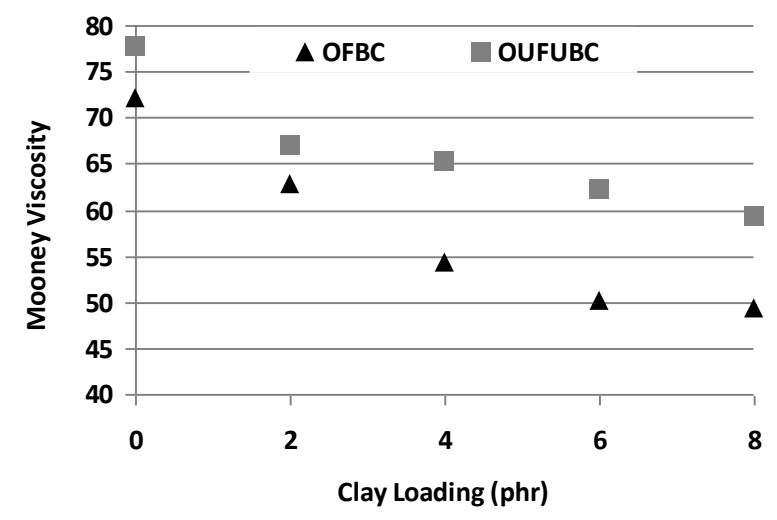

Fig 5. Mooney viscosity of organoclay filled latex crepe rubber composites

The reason for higher Mooney viscosities of OUFUBC composites compared to OFBC composites is the resistance to thermo-oxidative degradation by the natural antioxidants present in OUFUBC composites and some non-rubbers such as proteins act as filler for NR as reported in ASTM D 1646 - 04 standard.

Kader et al. (2010) showed Mooney viscosities that decreases between pure polymer and composites and that go through a minimum upon increase of filler concentration. Some arguments for explaining this effect, which can be summarized as follows: the reduction of viscosity upon increasing nanofiller concentration might be partly due to breakdown of platelets stacks and subsequent dispersion and exfoliation under shear, to alignment during flow and to some plasticizing action from the presence of the long chain organic modifier in the clay, possibly causing chain slippage over the clay platelets. As it is clearly shown here, the flow behavior of prepared organoclay filled crepe rubber composites does not exhibit a simple trend because of the miscellaneous and complex influences of polymer- organoclay interactions, degree of dispersion and orientationrelated features during flow.

The initial Mooney peak obtained from the Mooney curves of uncured organoclay filled latex crepe rubber composites has shown a greater reduction with the increase of organoclay loading as shown in Figure 6. 


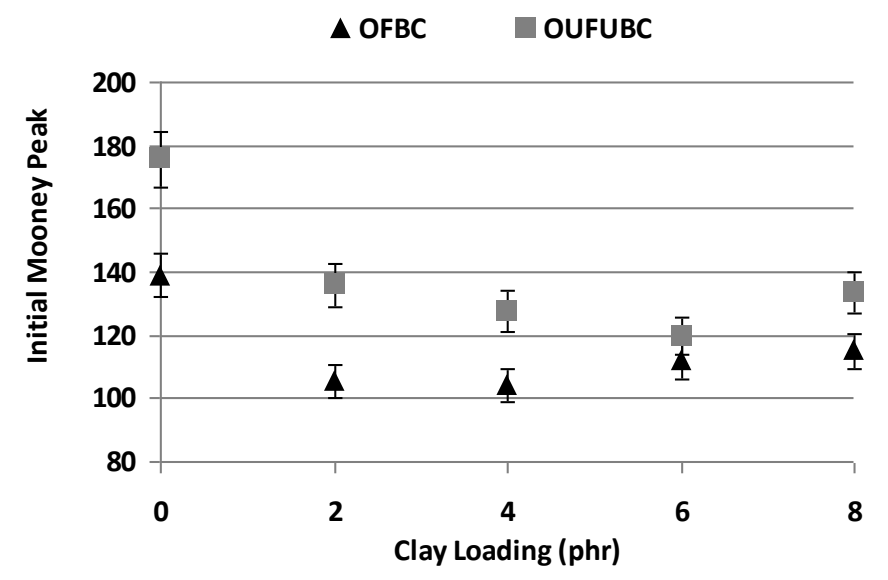

Fig. 6. Initial Mooney peak of organoclay filled latex crepe rubber composites

In both OFBC and OUFUB composites, initial Mooney peak has reduced up to 4 phr clay loading level and thereafter there is no indication of significant change with the increase of organoclay. As reported by the Malac (2010), the initial Mooney peak value can be used to describe the green strength of uncured NR. As shown in initial Mooney peak values, organoclay has a significant effect on green strength of organoclay filled latex crepe rubber. Plasticization effect of low molecular weight modifiers in the organoclay, the oxidation of NR by the copper and iron metal ions in organoclay and slip of molecules on the surface of layered aluminosilicate platelets/stacks could be the main reasons to reduce the green strength of organoclay filled latex crepe rubber.

In addition to Mooney viscosity, Mooney stress relaxation (MSR) data which provides the information on elasticity at low shear strain rate of the uncured rubber. Log-log plots obtained by the power law model for MSR are shown in Figure 7 and 8. 
H G I M Wijesinghe et al.

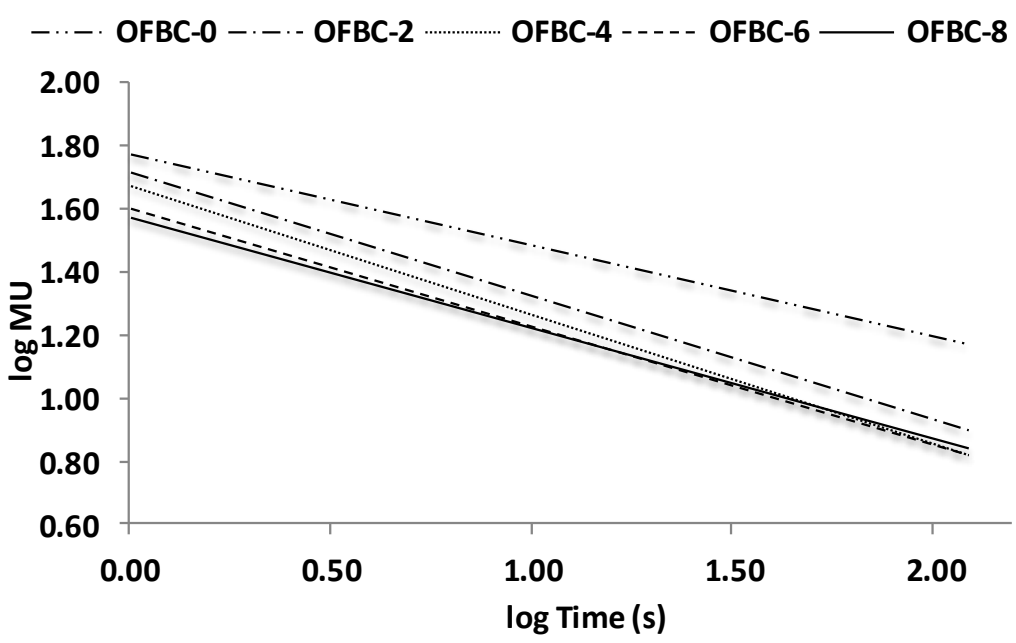

Fig 7. $\log -\log$ plot for Mooney stress relaxation OFBC composite

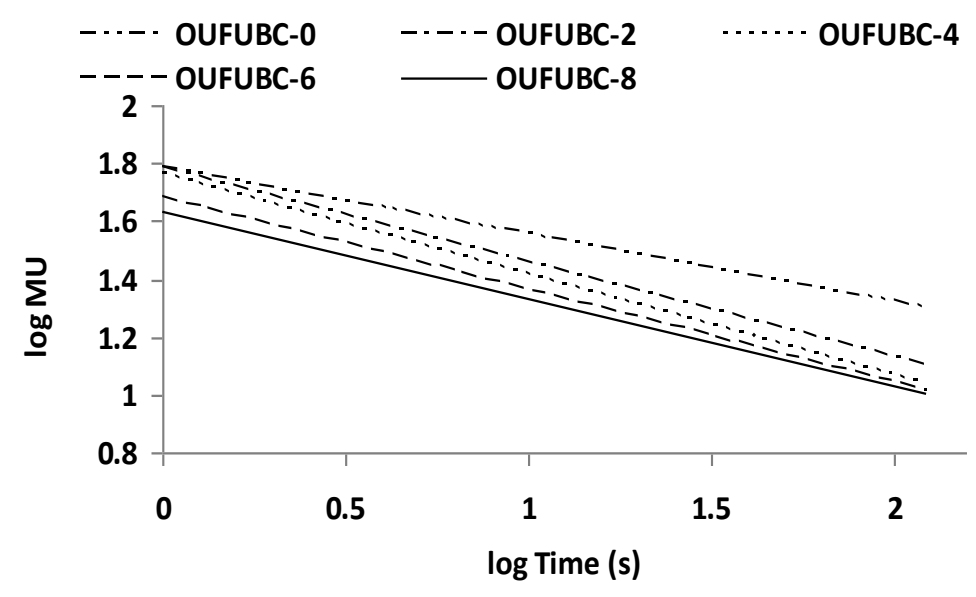

Fig. 8. $\log -\log$ plot for Mooney stress relaxation of OUFUBC composites

Mooney stress relaxation coefficients for the prepared organoclay filled latex crepe rubber composite samples are shown in Table 7 and Table 8 . As reported, the MSR coefficients of both
OFBC and OUFUBC composites are initially increased up to $4 \mathrm{phr}$ of organoclay loading level and then it reduces slightly when the organoclay loading is increased beyond $4 \mathrm{phr}$. Also 
the MSR coefficients of OFBC-0 and OUFUBC- 0 are the minimum and therefore, these samples have the higher elasticity compared to other composite samples filled with organoclay. From 0 to $4 \mathrm{phr}$ of OC loading, the elasticity of both OFB and OUFUB crepe rubber composites is reduced and then the elasticity increases when the organoclay loading increases because the exponent is inversely proportional to the elasticity of uncured composites of NR.

The stress relaxation behavior of natural rubber is a combination of both elastic and viscous response. Viscosity and stress relaxation behavior do not depend on molecular weight and non-rubber constituents in the same way. The rate of stress relaxation has been found to correlate with rubber structural characteristics such as molecular weight distribution, chain branching and gel content (Malac, 2009).

Long relaxation times and high amplitudes of stress relaxation suggest that the mechanism of structural relaxation involving large-scale displacements of isolated clusters of nanoparticles within the rubber matrix and vice versa may be the reason for the stress relaxation behavior of composites in this study according to Sukhy et al. (2010). Therefore, according to the MSR coefficient values maximum processability/mixing can be achieved at organoclay loading level of $4 \mathrm{phr}$ with a minimum elasticity.

Table 7. Mooney stress relaxation of $O F B C$ composites

\begin{tabular}{lll}
\hline Sample code & MSR coefficient $(\mathbf{a})$ & Constant $(\mathbf{k})$ \\
\hline OFBC-0 & 0.287 & 1.773 \\
OFBC-2 & 0.390 & 1.719 \\
OFBC-4 & 0.407 & 1.673 \\
OFBC-6 & 0.373 & 1.604 \\
OFBC-8 & 0.349 & 1.574 \\
\hline
\end{tabular}

Table 8. Mooney stress relaxation OUFUBC composites

\begin{tabular}{lll}
\hline Sample code & Exponent (a) & Constant (k) \\
\hline OUFUBC-0 & 0.232 & 1.786 \\
OUFUBC-2 & 0.330 & 1.788 \\
OUFUBC-4 & 0.348 & 1.761 \\
OUFUBC-6 & 0.320 & 1.683 \\
OUFUBC-8 & 0.302 & 1.634 \\
\hline
\end{tabular}


When compare the OFBC and OUFUBC composites, the higher elasticity has been achieved by OUFUBC composites. This may be due to natural anti-oxidants in the OUFUBC composites that can resist the thermal oxidative degradation of NR molecules by metal ions in crepe rubber prepared using organoclay. This resistance is less in OFBC composites and it has shown less elasticity when increase the organoclay loading level as molecular weight reduction is high due to oxidation. Also dispersion of organoclay can be predicted by the Mooney stress relaxation data. According to the results in Table 8, minimum elasticity of both uncured composites has been achieved at $4 \mathrm{phr}$ organoclay loading level. Therefore according to the Malac $\mathrm{J}$ this level would be the best processable organoclay loading level.

\section{Conclusion}

Organoclay filled fractionated bleached (OFBC) and unfractionated unbleached (OUFUBC) latex crepe rubber composites were successfully prepared by the addition of $5 \% \mathrm{w} / \mathrm{w}$ aqueous dispersion of organoclay in view of enhancing the degree of dispersion of organoclay with a clay recovery percentage more than $80 \%$.

Characterization of raw rubber properties revealed that initial plasticity $\left(\mathrm{P}_{\mathrm{o}}\right)$ and plasticity retention index (PRI) are adversely affected by the addition of organoclay. Organoclay accelerates the thermo-oxidative degradation of crepe rubber because of it contains higher concentration of iron and copper ions, even with 2 phr loading level accelerates the thermo-oxidative degradation. As a result, higher concentration of metal ions in the organoclay limits the organoclay applications in natural rubber.

Processability, as measured with low shear strain rate Mooney viscosity, has affected by the addition of organoclay. Significant reduction of Mooney viscosity of both grades of organoclay filled latex crepe rubber composites is caused due to combination effect of thermal oxidation and plasticization effect induced by the clay. However, elasticity, as correlated by the Mooney stress relaxation, information have proven that optimum dispersion of organoclay in NR can be achieved with $4 \mathrm{phr}$ clay loading level with a minimum elasticity and better processability.

\section{Acknowledgements}

Authors would like to acknowledge the technical support and the materials given by the Rubber Research Institute of Sri Lanka and Uva Wellassa University, Sri Lanka.

\section{References}

Alwis, G M C, Ratnayake, U N and Kottegoda, N (2013). Reinforcement and curing characteristics of organoclay filled natural rubber nanocomposites. Journal of the Rubber Research Institute of Sri Lanka 93, 89-103. 
Cantaloube, B and Cocard, S (2004). Revisiting the rheological characterization of NR using a Mooney viscometer. Kaut Gummi Kunstst 57 (4) 168.

Cassagnau, P and Barres, C (2010). Rheological behavior of rubbernanocomposites. In: Rubber Nanocomposites, Preparation, Properties and Applications. Pp.376-377 (Eds. Sabu Thomasand Ranimol Stephen) Singapore: John Wiley \& Sons (Asia) Ptv. Ltd.

Chonkaew, Wunpen, Withawat Minghvanish, Ulchulee Kungliean, Nutthaya Rochanawipart and Witold Brostow (2011). Vulcanization characteristics and dynamic mechanical behavior of natural rubber reinforced with silane modified silica. Journal of Nano Science and Technology 11, 20082024.

De Silva, K G K (2003). Value added grades of natural rubber. In: Hand book of Rubber Processing Technology, RRISL, pp (93) (Eds. Nugawela, A. and Seneviratne, W.M.G.) United Printers, Moratuwa.

Faheem, U (2008). Clays, nanoclays and montmorillonite minerals. Metallurgical and Materials Transactions. 39, Issue 12, pp 2804-2814, Retrieved October 23, 2015 from http://link.springer. com/article/10.1007\%2Fs11661-0089603-5.

Gatos, K G and Kocsis, J K (2010). Rubber/Clay Nanocomposites In: Rubber Nanocomposites, Preparation, Properties and Applications. Pp.169 175 (Eds. Sabu Thomasand Ranimol Stephen) Singapore: John Wiley \& Sons (Asia) Ptv. Ltd.

Kenkichi Murakmi (1972). Aging of natural and synthetic rubber and rubber products. 71 pp. Retrieved October 10 , 2014, from https://books.google.lk/ books?id=x00rAAAAYAAJ\&pg=PA71 $\& \operatorname{lpg}=$ PA71\&dq=natural+rubber + degrad ation + by + copper\&source $=$ bl\&ots $=\mathrm{KCx} 4$ vhdHzM\&sig=YKI1v95VWxpDnBJxr4 wO5JYw4s\&hl=en\&sa=X\&redir_esc $=y$ $\# \mathrm{v}=$ onepage \&q=natural\%20rubber\%20d egradation $\% 20$ by $\% 20$ copper $\& \mathrm{f}=$ false.

Kader, M A, Lyu, M Y and Nah, C (2006). A study on melt processing and thermal properties of fluoro elastomer nanocomposites. Composites Science and Technology 66, 1431-1443.

Malac, J (2009). Viscosity, relaxation and stability of natural rubber. The Open Macromolecules Journal 3, 41-44. Retrieved August 22, 2014, from the World Wide Web:http://www. benthamopen.com/tomacroj/articles/V00 3/41TOMACROJ.pdf.

Malac, J (2010). Mooney viscosity, mooney elasticity and processability of raw natural rubber. Journal of Materials Science and Engineering with Advanced Technology 3, 67-87. Retrieved August 22, 2014, from the World Wide Web: https://www.google.lk/webhp?sourceid= chrome-instant\&ion $=1 \&$ espv $=$ 2\&ie=UTF-8\#q=MOONEY+ VISCOSITY,+MOONEY+ELASTICIT $\mathrm{Y}+\mathrm{AND}+\quad \mathrm{PROCESSABILITY}+\mathrm{OF}+$ RAW+NATURAL+RUBBER Scientific Advances Publishers.

Nicolaas, M H (2003). Durability of rubber products, development of new antidegradants for long term protection, Thesis. (pp.11) Twente University, Twente University Press, Netherlands.

Onyeagoro, G N (2013). Reactive compatibilization of Natural Rubber (NR)/Carboxylated Nitrile Rubber (XNBR) blends by maleic anhydridegrafted-polyisoprene (MAPI) and epoxy 
H G I M Wijesinghe et al.

resin dual compatibilizers. Journal of Engineering and Science (IRJES,) 2 (3), 07-16. Retrieved November 25, 2014, from www.irjes.com.

Ratnayake, U N, Premathunga, D E, Peiris, C, Karunaratne, V and Amarathunga, G A J (2015). Effect of polyethylene glycol-intercalated organoclay on vulcanization characteristics and reinforcement of natural rubber nanocomposites. Journal of Elastomers and Plastics pp 1-17.

Ratnayake, U N, Sarath Kumara, P H, Siriwardene, T A S, Warnajith, A K D and Rohanadeepa, V C (2009). Effect of metal ions on quality of crepe rubber. Project No. RRPD/D/EMC/2011/05 in Annual Review of the Rubber Research Institute of Sri Lanka, pp.151.

Ratnayake, U N and Peiris, C (2010). Natural Rubber/Layered Silicate Nanocomposite for Building Applications. International Conference on Sustainable Built Environment, 6976. Retrieved May 27, 2014, from the World Wide Web: http://www.civil.mrt.ac.lk/ conference/ICSBE_2010/vol_03/11.pdf .

Ratnayake, U N et al. (2011). Effect of iron in processing water on quality of crepe rubber. Journal of the Rubber Research Institute of Sri Lanka 91, 1-14

Ratnayake, U N and Ketipearchchi, J (2012). Natural Rubber/clay nanocomposites: effect of organic modifier of clay on cure characteristics and mechanical properties. Proceeding of International Polymer Science and Technology Symposium, Volume 1,
University of Sri Jayewardenepura Sri Lanka, Retrieved October 12, 2015 from http://journals.sjp.ac.lk/index.php/IIUPS T/article/ view/622.

Rogers, M B, Tracey, D S and Waddell, W H (2005). Production, classification and properties of NR - Part 2. Journal of Materials Science and Engineering with Advanced Technology Rubber World 232 6, pp 41.

Senevirthne, W M G and Kumara, P H S (2003). Pale crepe and Sole crepe. In: Handbook of Rubber-Processing Technology, RRISL (Eds. Nugawela, A and Seneviratne, W M G) 2, pp.34-57. United Printers, Moratuwa.

Sukhyy, K M, Privalko, E G, Privalko, V P and Burmistr, M V (2010). Thermoelasticity and stress, relaxation Behavior of, Synthetic Rubber/ Organoclay Nanocomposites In: Rubber Nanocomposites, Preparation, Properties and Applications. pp.631648 (Eds. Sabu Thomasand Ranimol Stephen) Singapore: John Wiley \& Sons (Asia) Pte Ltd.

Utracki L A (2004). Clay-Containing Polymeric Nanocomposites, Vol. 1, Rapra Technology Limited. Shrewsbury, UK.

Address for correspondence: Dr Upul Ratnayake, Head, Raw Rubber Process Development \& Chemical Engineering Dept., Rubber Research Institute of Sri Lanka, Telewela Road, Ratmalana, Sri Lanka.

e-mail:un_ratnayake@yahoo.co.uk 
Journal of the Rubber Research Institute of Sri Lanka (2015) 95, 39-57 